\title{
Students' Perceptions about the Use of Minimalist Robotic Games in Geography Education
}

\author{
Soon Singh BIKAR ${ }^{1}$ \\ University Malaysia Sabah \\ MALAYSIA
}

\author{
Sabariah SHARIF ${ }^{2}$ \\ University Malaysia Sabah \\ MALAYSIA \\ Balan RATHAKRISHNAN4 \\ University Malaysia Sabah \\ MALAYSIA
}

\author{
Rosy TALIN 3 \\ University Malaysia Sabah \\ MALAYSIA
}

${ }^{1}$ Corresponding author: Dr, University Malaysia Sabah, Faculty of Psychology and Education, Kota Kinabalu, Malaysa, soonbs [at] ums.edu.my. ORCID: 0000-0001-7272-484

${ }^{2}$ Assoc. Prof, Sabariah Sharif University Malaysia Sabah, Faculty of Psychology and Education, Kota Kinabalu, Malaysa, sabariah [at] ums.edu.my. ORCID: 0000-0001-5357-4567

3Unversiti Malaysia Sabah, Faculty of Psychology and Education, Kota Kinabalu, Malaysa, rostalin [at] ums.edu.my. ORCID: 000-0001-7212-9629

${ }^{4}$ Assoc Prof, University Malaysia Sabah, Faculty of Psychology and Education, Kota Kinabalu, Malaysa, rbhalan[atlums.edu.my. ORCID: 0000-0003-4136-4495

\begin{abstract}
Recent trends show the number of students studying geography in upper secondary school is declining. Among the reasons identified is that geography is perceived as a very tedious and difficult subject to study. With the rapid development of technology in the twenty-first century, the use of multi-media tools and technologies in education have given a new dimension to the process of teaching and learning. One of the most widely used technological tool is robots. Therefore, this study was conducted to evaluate the perceptions of high school students who are using minimalist robotic games for teaching and learning activities in Geography. Qualitative research methods were used to collect the research data. In total there are 15 groups of students participating in the Science Technology Engineering and Mathematics (STEM) Education Carnival; each group consists of three to six members who have created a minimalist robot game for the subject of Science, Mathematics and Social Sciences. However, there are only two groups of students consisting of two male and four female students who created games for Geography. Therefore, a purposive sampling method was used to select students from these two groups. Six students who participated in the development of a minimalist robotic game for Geography in the STEM education carnival were selected and interviewed. Semi-structured interviews were conducted at the end of the carnival. The data analysis of the interview shows five out of six students had a very positive perception of using minimalist robotics in Geography education. In addition, this study also showed that the use of minimalist robotics in the teaching and learning of Geography also changed the interest and attitudes of students towards learning Geography. The application of minimalist robotics also enhances students' intrinsic motivation to study Geography. implications of this study suggest that minimalist robotics games are an alternative technology teacher can integrate into teaching and learning activities for Geography in schools to enhance students' interest in learning about this subject.
\end{abstract}

\section{Keywords}

Minimalist Robotic, Geography, Interest, Intrinsic Motivation 
Geography is a discipline that studies the organization of space and the environment; it involves study of the interrelationships and interactions occurring between people as individuals and communities, between people with the environment, and between environmental components at local and global scales (Malaysian Ministry of Education, 2017). In the Malaysian education system, Geography is required for study by all lower secondary school students (Grades 7 to 9). At the upper secondary school level (Grades 10 to 12), Geography is an elective subject. The Geography Curriculum was introduced into schools to equip students with geographical knowledge; mastery of geographical skills; and to enhance moral value to create Malaysian citizens who are competitive, knowledgeable and capable of responsibly managing the country's environments and resources. In addition, the Geography Curriculum was also introduced into schools to enhance student understanding about the physical and human environment; to foster a spirit of patriotism; and to become aware of local and global natural phenomena. However, the number of students taking this subject in the upper secondary school decreases each year. One of the main reasons put forward is that Geography is perceived as a boring subject because teachers still use conventional methods to teach in the classroom (Artvinli, 2010a; Singh, Rathakrishnan, Sharif, Talin, \& Eboy, 2016). In addition, the findings also show that students are not interested in learning this subject because it is difficult to understand (Singh, Rathakrishnan, Talin, \& Kiflee, 2018). As such, this has led to the decline in the number of schools offering Geography at upper secondary school level (Singh et al., 2016).

This aforementioned issue has prompted a number of studies to be conducted about how to increase student interest in Geography in Malaysia and abroad. For example, Aminudin (2014) and Artvinli, 2010b, 2017) conducted a multimedia effectiveness study to increase indigenous students 'interest in Geography and found that multimedia users succeeded in attracting indigenous students' interest in Geography. Another similar study conducted by Juniarti (2014) noted that using the interactive mind mapping and mobile learning in teaching Geography enhances students' understanding about and interest in learning about the hydrosphere. Overseas studies conducted by Musumba (2019), Sulistianingsih (2019) Steegen, Hasendonckx, and De Cock (2018) and Hong (2016) also conclude the use of information and communication technology (ICT) elements can increase student interest in Geography.

The rapid growth of twenty-first century technology around the world has introduced a unique approach to supporting the teaching and learning process in schools. For example, the introduction of robotics in the classroom learning process (Lytridis, Bazinas, Papakostas, \& Kaburlasos, 2019). In the early stages of this robotics education program, it was only used to teach the topic of programming (Zhong \& Xia, 2020).

However, in the new norm, robotics also began to be used and integrated into the teaching of Mathematics (Leoste \& Heidmets, 2019), Languages (Bravo, Gonzalez, Di Blas, \& Bonarini, 2019), and Science (Zhang, Lai, \& Xu, 2020). In the Malaysian 
context, the Ministry of Education have invested heavily in school facilities for the infusion of robotics in education. However, the integration of robotics into teaching has given greater priority to STEM subjects (Zaharin, Sharif, Singh, Talin, Mariappan \& Mohanaraj et al., 2020). Although a growing body of research has specifically examined the relationship between robotics-integrated learning and interest in learning for school children in several subjects, there is limited research on the relationship between robotics-integrated learning in secondary schools and student interest in learning Geography. It is therefore important to investigate school students' perceptions about integrating minimalist robotics game in learning Geography because it will add new value to study about the implementation of robotics games in Geography education.

\section{Minimalist Robotics Education Program}

Program Pendidikan Robot Minmalis (Minimalist Robotics Education Program) is a 3-month program designed to promote student interest in Science, Technology, Social Science, Engineering and Mathematics (STEM) subjects through using Minimalist Robots called "Comel" with the application of Scratch4Arduino (S4A) programming (see Figure 1). Students involved in the program consisted those in Form One (Grade 7) who are 13 years old. The Minimalist Robotics Education Program was started by training five selected students from fifteen secondary schools in Kota Kinabalu. A total of 75 students were selected for this program. The main goal of the program is to train students to use Sctah4Arduino (S4A). Those trained students will develop minimalist robotic-based games to be applied in the learning process. The duration of this training period is 64 hours (12 days). The content of this training compromised four sections:

Section 1: Introduction to sequential thinking

In Section 1, students were trained to think like a robot. A total of four hours were located to guide students in the design of flow charts so as to provide direction for robot movements.

Section 2: Introduction to the hardware of the Minimalist Robot

Section 2 is an introduction to the components used to build a simple robot. Students were asked to install and open all components to build a robot. The main objective of this section of the course was to expose and enhance students' confidence to install the robots. Robots that were installed by the students were then tested to identify the problems and strengths of the built-in robots. Overall, 20 hours were allocated in this part to ensure the students to master the content of this section.

Section 3: Introduction to the S4A programming

In the third section, there were 20 hours of training provided to students to expose them to S4A programming. Students were taught the functions of S4A and how to connect S4A with a robot. Students were also taught the basics of the robot's movement such as right, left, back and front. 


\section{Section 4: Advanced S4A}

In Section 4, students were taught advanced programming. A total of 20 hours were allocated for this section. Among the content taught was the coding of the robots' movements with various movement barriers. The barriers included in this section were the timing of movement and movement of the robot in the manner specified by the robot's sensor.

Students who completed the course were invited to participate in the STEM Education Carnival at Kota Kinabalu. The carnival occurred four weeks after the students completed the course. The main goal of the carnival is to encourage students who have participated in the Minimalist Robotics Program to apply what they have learned. To participate in this carnival each school has to send a group of students that consists of three to six students. The group of students who participate in the competition will need to create a minimalist robotic based learning game. A total of 15 groups of students participated in the carnival and created various teaching and learning games based on minimalist robots. However, only two groups of students created learning games for Geography. Each of these groups consisted of three students.

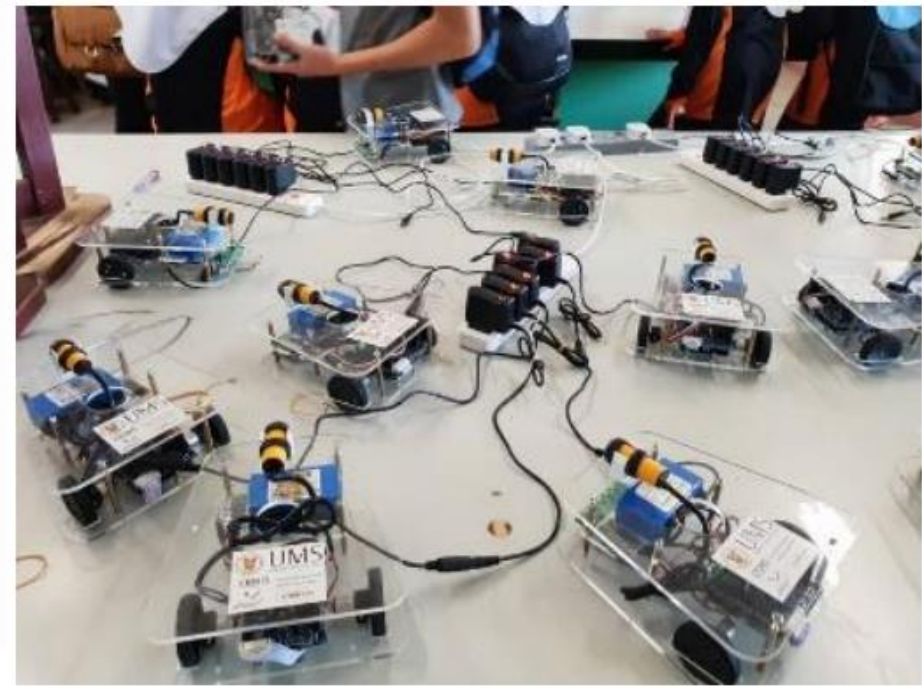

Figure 1. The Minimalist Robot "Comel” that are used throughout the Minimalist Robot Education Program

\section{Method}

The data of this study were obtained using a qualitative research method. Qualitative research data were obtained in semi-structured interviews. This qualitative research method is used in this study as it can help researchers understand the issues that will be addressed from the ideal individual in-depth study (Balan, Samsudin, Singh, \& Juliana, 2017; Rose \& Johnson, 2020).

\section{Sample Study}

There are fifteen schools participating in the STEM Education Carnival. Only two schools sent representatives and created minimalist robotics game projects about 
Geography. Therefore, a purposive sampling method was used to select two groups of students. The first group consisted of three students who created a learning project based on a major tourist destination in Malaysia (Kawasan Pelancongan di Malaysia.) The second group also consisted of three students, and they created a learning project based on drainage in Malaysia (Sungai Malaysia). Total of six students from Grade 7 from across the two groups of students were selected for this study.

\section{Interview}

Interviews were conducted immediately after the STEM Education Carnival. Six students who participated and won prizes in the carnival were interviewed. The interview sessions were held in the school's meeting room to ensure that there was no outside interference. Each interview session lasts between 35 to 45 minutes.

\section{Data Analysis}

In the current study, a thematic analysis method was used to analyze the qualitative data. The main reason for using this method of analysis was that it is very flexible to employ within different theoretical perspectives and it was not embedded in the traditions of particular theories (Grbich, 2012). The audiotapes of student interviews were transcribed verbatim. The transcribed versions were then checked again with the tapes for accuracy. Further, the transcriptions were imported into NVIVO version 10 software for analysis. The imported data into NVIVO software were then re-read several times to familiarize the researcher in depth with the data. Open coding was used to create categories or related codes from the initial points, this having been identified in the data familiarization process. The open-coding feature of NVIVO allowed the researcher to generate many initial codes for potential themes and patterns by tagging and naming selections of text within each data item. The initial codes created during the open coding were refined, and the refined codes were then analyzed with a view to re-arranging and collating the different codes into potential themes. Such a process resulted in the emergence of three main themes: attitude, interest and intrinsic motivation.

\section{Findings}

\section{The Use of Minimalist Robotics Games in Learning Geography}

Data analysis showed that five of the six students interviewed had a very positive view of using minimalist robotics in the classroom for learning purposes. This is because, in this minimalist robot-based learning, students need to create their own learning content and responses to the problem-solving task given by the teacher. For example, Respondent 1 said:

Sia sangat setuju sekiranya robot ini dipakai dalam pengajaran Geografi...Ia amat membantu saya dalam menyediakan bahan untuk belajar sendiri... emm guna robot ini juga ndak susah... senang jak bha... Kita perlu belajar cod cod dia sahaja... Ia sangat seronok.

I totally agree if this minimalist robot is used in Geography lessons ... It really helps me to prepare the material for my own learning ... using this robot is also not hard .. it's easy ..We just have to learn the code... It's fun. 
Similar views were responded by Respondents 2, 3, and 4 .

Sia amat setuju kalau buli ini ganti robot untuk ajar Geografi. Melalui robot ini kita bukan hanya belajar mata pelajaran Geografi tapi saya juga di ajar untuk berfikir untuk gerakkan robot ikut itu garisan tepat. Kami juga bebas untuk merancang dan mencipta game permainan geography berasaskan robot minimalist untuk belajar.

I totally agree if possible, we replace and use minimalist robotics to teach Geography. Through this robot we are not only learning the subject of Geography, but I am also taught to think about moving the robot along that exact line. We are free to plan and create our own Geography game by using the minimalist robot.

Respondent 5 further explained that the use of a minimalist robotics game in his study changed his attitude toward Geography. The respondent thinks that Geography is very difficult to learn and a very boring subject. However, the respondent found using minimalist robotics in learning Geography to be more interesting and enjoyable.

Tidak ni... saya anggap Geografi subjek yang susah dan bosan untuk belajar. Tapi dengan guna robot ni macam seronok pula kan...saya mula tetarik pula untuk guna. Sebab itu saya cipta projek pengenalan kawasan pelancongan utama di Sabah dengan robot... So kalau buli la kan saya mau cikgu cikgu Geografi pakai bha ini robot untuk ajar.

No ... I consider Geography a difficult subject and bored of learning. But using this robot seems fun ... I'm starting to get interested in using it. That's why I created the project of introducing Sabah's major tourist areas with robots. So, if possible, I want my Geography teachers to use minimalist robots to teach us.

\section{Effect of Minimalist Robotics Games on Students Interest to Geography}

This question is posed to students to find out their level of interest in Geography. Data analysis of the interview showed that four of six students indicated they were less interested in Geography because they had to remember maps, names of places and also to develop geographical skills for mapwork calculations. However, students' perceptions of and interest in Geography started to change as they began to integrate minimalist robotics games into learning activities for Geography. For example, Respondent 4 explained that:

Bagi saya la kan...saya tidak minat subjek ini... Ia merupakan subjek yang baru bagi saya... But saya mula-mula macam sudah minat Geografi apabila guru minta kumpulan saya buat projek...saya tidak tau pula boleh guna robot untuk belajar Geografi...Emm kumpulan saya bina projek robot untuk ajar gunung berapi... So macam besr pula... saya mula minat dengan subjek ini...

For me it is ... I am not interested in this subject ... It is a new subject for me because in primary school I don't learn Geography... But I was first and foremost interested in Geography when my teacher asked my group to do a project based on minimalist robot. I did not even know we can use robots to study Geography ... my group was building a robot project to teach rivers in Malaysia. So, it's like a big thing for me and my group members...my team members manage to build a game by name "Sungai Di Malaysia" (River in Malaysia). This has changed my thought for Geography and got interested in this subject.

To further investigate this finding, the researcher asked the participants how the Minimalist Robotics Education Program and Karnival pendidikan STEM (STEM Education Carnival) impacted on their interest in Geography. The responses were that learning with minimalist robotics is fun and improved their competence in 
learning Geography. In addition, the "Sungai Malaysia" (Malaysia River) game created by the group members helped them to easily understand the name and location of the river.

\section{Respondent 6 also commented:}

Oh... Mula-mula saya tidak minat ini Geografi... Dua... kali ujian saya gagal. Beliau saya suruh saya ambil tuisyen... Tapi sekarang saya sudah mula minat ini subjek. Saya mula minat bila guru suruh kami buat projek untuk bertanding. Saya dan kawan saya cipta games mengenai Sungai di Malaysia...kami berkerja keras... saya mula minat sudah dengan Geografi ni...

Oh .. At first, I didn't like this Geography ... Second ... I failed in my monthly test. My father told me to get some tuition... But now I've started to take interest in this subject. I became interested when my teacher asked us to do a project to compete. My friends and I created Malaysia river games ... we worked hard ...This has sparked my interest interest in Geography.

Respondent 6 elaborates further to say that learning Geography through minimalist robotics games is fun because students have the autonomous power to plan and create games to learn and understand a Geography topic. In this game, the members of the group and I are free to create game obstacles and questions that need to be answered at each station where the robot stops. This is very different from the traditional learning situation where teachers teach, and students only need to listen and understand. This new situation caused my interest in Geography to change. I just found out that robotics games can be used to explore Geography.

Respondent 3 explained the use of roboticss in Geography not only increased his interest in Geography but also his interest in Mathematics and Science. The respondent also plans to continue studying robotics in higher education.

Saya memang minat Geografi.... Sebab ia merupakan mata pelajaran yang baru bagi saya... Tapi la kan bila guna ini robot minat saya juga bertambah untuk belajar Sains dan Matematik... Saya sudah bercita-cita mau sambung belajar bab robot dan jadi pencipta robot.

I really love Geography.... Because this is a new subject for me .. But when I use this robot my interest is also increased to study Science and Mathematics. I have the ambition to continue my studies on robotics and create robots.

\section{Effect of Minimalist Robotics Games on Students Motivation and Excitement for Learning Geography}

Data analysis of the interview with five out of six students said they were not motivated and did not enjoy studying Geography. Therefore, their achievement in this subject was not satisfactory, thus they were forced by the parents to attend additional tuition. However, they became motivated and excited when using robotics to do projects in Geography. It is because of the robotics program that students need to plan, search for materials, read and analyze their own materials to complete the project. Such activities have added to their enjoyment of learning. For example, Respondent 1 explained that:

Seperti saya kata tadi... tidak bermotivasi untuk belajar Geografi kerana ia subjek yang susah mau difaham. Tapi kan lepas saya mula bermotivasi untuk belajar subjek ini apabila guru minta kami buat projek Geografi dengan guna permainan robot. Untuk buat projek ini saya perlu banyak cari bahan sendiri mengenai Geografi dan membaca dan memahami... Ia lebih kepada mempellajari sendiri bha... Sangat siuk ni.. Dulu saya perlu dengar guru mengajar dan rujuk buku 
teks sahaja. Tapi sekarang saya perlu rujuk internet, buku dan akhbar. Sekarang saya amat bermotivasi belajar Geografi lebih-lebih lagi sudah tahu itu guna robot.

As I said earlier ... not motivated to study Geography because it is a difficult subject to understand. But I got motivated to study this subject when my teacher asked us to do a Geography project using robot games... to do this project I need to find a lot of materials myself about Geography and read and understand... It is more to self-learning bha... Very interesting this... Last time I had to listen to the teacher teach and use textbook only. But now I need to refer to the internet, books, and newspapers. Now I am motivated to learn Geography now that I know can use robot.

\section{Discussion}

One of the main findings of this study is that students are very positive about the use of minimalist robotics in the teaching and learning of Geography. The findings of this study align with the findings from previous studies which show the use of robots in teaching has a positive reaction from students to the subjects they are learning (Ching, Yang, Wang, Baek, Swanson \& Chittoori, 2019). Researchers argue that one of the factors contributing to student change in robot-based learning is that it engages and promotes active participation from students. In addition, students also need to work hard to solve every problem they encounter during playing the robotic game, for example, moving the robot through the obstacles from one station to another and answering all the question given at each station. This finding is supported in a study by Conrad, Polly, Binns, and Algozzine (2018) who report that robotics-based teaching promotes student engagement in a given lesson. Therefore, it will interest the students and change their perceptions and attitudes towards a particular subject being taught in school.

The findings of this study also show the integration of minimalist robotics games in the teaching and learning of Geography has also increased student interest in learning. This study is aligned with the findings from a study conducted by Zhang, $\mathrm{Xu}$, Yang, Lai, and Wong (2018) who show that using robots as a simulation game increases students' interest in Science and Technology. Similar findings were reported by a study conducted by Taylor and Baek (2018). Researchers think that robot games are of interest to students because the shapes of the robots come in a variety of colors and movements. As such, it helps students to understand the content of the subjects being taught and subsequently increases student interest in those subjects. This view is supported by Jackson, Mentzer, and Kramer-Bottiglio (2019) who described that a robot is attractive, multi-colored and has a voice output to engage students in playing and understanding the content of the lessons desired to be conveyed by the teacher.

This study also shows that minimalist robotics games in teaching and learning also enhance students' intrinsic motivation towards Geography. Interview data shows that students involved themselves and took part in the robotics competition because they wanted to learn the content of the lessons and increase their knowledge about robotics. In addition, researchers argue that minimalist robotics games also increased the levels curiosity amongst students. As a result, this has 
encouraged students to volunteer themselves in every learning and facilitating activity conducted by the teacher. This statement is supported by a study conducted by Chame, Mota, and da Costa Botelho (2019). Overall findings from this study can serve as a benchmark for introducing robotics games in Social Science subjects.

\section{Conclusion}

This study shows that the use of minimalist robotics games gives a new dimension to integrating robotics into the teaching and learning of Geography in schools. The findings of this study show the integration of minimalist robotics in the teaching of Geography can change the perception of students who long thought that Geography is a dull and difficult subject to learn. However, it is quite difficult to make a comprehensive generalization on the use of minimalist robotics games in Geography due to a small study sample. Therefore, a larger scaling study can be conducted so that the findings of this study can be generalized.

\section{References}

Aminudin, A. (2014). Kesan interaksi media pengajaran, kaedah belajar, dan tahap pencapaian pelajar terhadap tahap kefahaman konsep gerakan melalui tugasan POE. (Doctoral dissertation). Universiti Utara Malaysia

Artvinli, E. (2010a). Teaching styles of geography teachers. Electronic Journal of Social Sciences, (9), 33, pp. 387-408. Retrieved from https://dergipark.org.tr/tr/pub/ esosder/issue/6147/82543

Artvinli, E. (2010b). The contribution of geographic information systems (GIS) to geography education and secondary school students' attitudes related to GIS, Educational Sciences: Theory and Practice; 10, (3), 1255-1292. Retrieved from https://files.eric.ed.gov/fulltext/EJ919854.pdf

Artvinli, E. (2017). What is innovative geography teaching? A perspective from geography teachers, Journal of Education and Training Studies, 5, (6), 9-23. DOI: https://doi.org/10.11114/jets.v5i6.2383

Balan, R., Samsudin, A., Singh, S., \& Juliana, J. (2017). Job preferences among marginalised and non-marginalised youths: A multi-ethnic study in sabah. Pertanika Journal of Social Sciences \& Humanities, 25, 55-65. Retrieved from https://www.academia.edu/25641665/Job_Preferences_among_Youth_A_Multiethn ic_Study_in_Sabah

Bravo, F. A., Gonzalez, E., Di Blas, N., \& Bonarini, A. (2019, June). Robots at school: supporting humanities teaching through robots-based storytelling. In EdMedia+ Innovate Learning. Association for the Advancement of Computing in Education (AACE) (pp.162175).

Chame, H. F., Mota, F. P., \& da Costa Botelho, S. S. (2019). A dynamic computational model of motivation based on self-determination theory and cann. Information Sciences, 476, 319-336. https://doi.org/10.1016/j.ins.2018.09.055

Ching, Y.-H., Yang, D., Wang, S., Baek, Y., Swanson, S., \& Chittoori, B. (2019). Elementary school student development of STEM attitudes and perceived learning in a STEM integrated robotics curriculum. TechTrends, 63(5), 590-601. https://doi.org/10.1007/s11528-019-00388-0 
Conrad, J., Polly, D., Binns, I., \& Algozzine, B. (2018). Student perceptions of a summer robotics camp experience. The Clearing House: A Journal of Educational Strategies, Issues and Ideas, 91(3), 131-139. https://doi.org/10.1080/00098655.2018.1436819

Grbich, C. (2012). Qualitative data analysis: An introduction (pp. 10-11). London: Sage.

Hong, J. E. (2016). Social studies teachers' views of ICT integration. Review of International Geographical Education Online (RIGEO), 6(1), 32-48. Retrieved from http://rigeo.org/download/3116/

Jackson, A., Mentzer, N., \& Kramer-Bottiglio, R. (2019). Pilot analysis of the impacts of soft robotics design on high-school student engineering perceptions. International Journal of Technology and Design Education, 29(5), 1083-1104. https://doi.org/10.1007/s10798-018-9478-8

Juniarti, R. D. (2014). Pengembangan media mobile learning dengan aplikasi schoology pada pembelajaran geografi materi hidrosfer kelas x SMA negeri 1 karanganyar. (Doctoral dissertation). Universitas Sebelas Maret.

Leoste, J., \& Heidmets, M. (2019). The impact of educational robots as learning tools on mathematics learning outcomes in basic education. Digital Turn in Schools-Research, Policy, Practice (pp. 203-217). Singapore: Springer. https://doi.org/10.1007/978981-13-7361-9_14

Lytridis, C., Bazinas, C., Papakostas, G. A., \& Kaburlasos, V. (2019, April). On Measuring Engagement Level During Child-Robot Interaction in Education. In International Conference on Robotics and Education RiE 2017 (pp. 3-13). Cham :Springer. https://doi.org/10.1007/978-3-030-26945-6_1

Malaysian Ministry of Education. (2017). Malaysia education blue print 2013-2025. Kuala Lumpur: Permodalan Nasional Berhad.

Musumba, M. A. (2019). Integration of information communication technology (ICT) in the instruction of geography in secondary schools in Matungu, Kakamega-Kenya (Doctoral dissertation) Moi University

Rose, J., \& Johnson, C. W. (2020). Contextualizing reliability and validity in qualitative research: toward more rigorous and trustworthy qualitative social science in leisure research. Journal of Leisure Research, 50(4), 432-451. https://doi.org/10.1080/00222216.2020.1722042

Singh, S. S. B., Rathakrishnan, B., Sharif, S., Talin, R., \& Eboy, O. V. (2016). The effects of geography information system (GIS) based teaching on underachieving students' mastery goal and achievement. Turkish Online Journal of Educational TechnologyTOJET, 15(4), 119-134. Retrieved from https://files.eric.ed.gov/ fulltext/EJ1117621.pdf

Singh, S. S. B., Rathakrishnan, B., Talin, R., \& Kiflee, D. N. A. (2018). Pengintergrasian sistem maklumat geografi (GIS) dalam pengajaran dan pembelajaran gegrafi: Kajian kes di sekolah bestari luar bandar di sabah. $e$-Bangi, 14(2), 112-122.

Steegen, A.; Hasendonckx, F.; Cock, M. (2018). Can an Interactive learning path on a tablet pc counter misconceptions on the formation of clouds and wind? Review of International Geographical Education Online (RIGEO), 8 (1), 53-73. Retrieved from http://www.rigeo.org/vol8no1/Number1Spring/RIGEO-V8-N1-3. 
Sulistianingsih, E. (2019, June). The use of youtube as a geography learning source in high schools. in 3rd international conference on current issues in education (ICCIE 2018). Atlantis Press.

Taylor, K., \& Baek, Y. (2018). Collaborative robotics, more than just working in groups. Journal of Educational Computing Research, 56(7), 979-1004. https://doi.org/10.1177/0735633117731382

Zaharin, N. L., Sharif, S., Singh, S. S. B., Talin, R., Mariappan, M., Mohanaraj, N., ... Suppiah, P. (2020). Promoting students' interest, attitude and intrinsic motivation towards learning STEM through minimalist robot education programme. International Journal of Service Management and Sustainability, 4(1), 41-66. Retrieved from http://www.ijsmssarawak.com/ijsms_vol_4_1/3.pdf

Zhang, J. L., Xu, W. W., Yang, T., Lai, I. K. W., \& Wong, L. P. (2018, July). Robots-stimulating İnterest and motivating learning in science and technology. In 2018 International Symposium on Educational Technology (ISET) (pp. 226-229). IEEE.

Zhang, J., Lai, I. K. W., \& Xu, W. (2020). Motivating students' learning in science and technology by using robots. International Journal of Innovation and Learning, 27(4), 395-410. DOI: 10.1504/IJIL.2020.107620

Zhong, B., \& Xia, L. (2020). A systematic review on exploring the potential of educational robotics in mathematics education. International Journal of Science and Mathematics Education, 18(1), 79-101. https://doi.org/10.1007/s10763-018-09939-y

\section{Biographical Statements}

Soon Singh BIKAR is a senior lecturer of Geography Education in Faculty of Psychology and Education, University Malaysia Sabah, Malaysia. He holds a PhD in Geography Education (Macquarie University, Sydney), M.Ed. in Educational Psychology (University of Malaya) B.A. (Hons) Geography (University of Malaya) and Teacher Training Certificate (Malay study). He has seven years of experience in teaching in Primary school, eight years in secondary school and currently as a lecturer in UMS. His research interests are in mixed methods research, geographical education, applying geography Information system (GIS) in teaching geography, creativity in teaching and learning, motivation, and learning styles. He has also written a number of book chapters, among them are Matos or Reality of Integrating GIS in Geography Education in Malaysia and Dilemma in Mastering Geography Skills among students of rural schools in Sabah. He is an active member of National Council for Geography Education (NCGE), Mixed Methods International Research Association and Australian Association for Research in Education.

Sabariah SHARIF is an Associate Professor and Dean of the Department of Psychology and Education in University Malaysia Sabah, Malaysia. She holds a PhD in Education and a MA in Educational Technology from University of Bath, England, Diploma in Education (Bio/Science) and a B.Sc (Hons) in Marine Science from Universiti Kebangsaan Malaysia. She has experience teaching in a secondary school for five years and is currently working as a university lecturer for the last twenty-three years. Her research interest includes robotics in education, educational technology and science education. She is an active member of Persatuan Robotik Pendidikan Komuniti (CERA) an organization aiming to expose students with STEAM learning through minimalist robotic projects. She has published her work in Malaysian and International journals including Malaysian Journal of Social Sciences and Humanities, World Journal of Management and Behavioral Studies and International Journal of E-learning Practices (IJELP). 
Rosy TALIN is lecturing at the Faculty of Psychology and Education, University Malaysia Sabah, Malaysia in the field of Curriculum and Instruction. She holds a PhD in Curriculum and Instruction (University Malaysia Sabah), M.Ed. in Educational Management and Administration from (University of Manchester, United Kingdom), Postgraduate Diploma in Education and B.A. (Hons) Linguistic (National University of Malaysia). She has experience teaching in Secondary school for three years and teaching in the university for the last twenty-four years. Her research interest is in teaching methodology for History. She has written papers regarding the inculcation of Historical Thinking Skills and Higher Order Thinking Skills in teaching History. Her other interest is in helping parents to educate their children at home.

Balan RATHAKRISHNAN is Associate Professor in Faculty of Psychology and Education, University Malaysia Sabah. He specialized in youth and community development program in UMS. He also won World Inventor Award from Korea in 2013 in field of research and education category for social sciences. His research focuses on youth, creativity, innovation and intervention for social problems for youth. Dr Balan Rathakrishnan obtained his degree, M.A and Ph.D (Psychology) from National University of Malaysia (UKM). He is a member of the Malaysian Institute of Management (MIM) and member of the Malaysian Institute of Human Resource Management (MIHRM)-formerly known as The Malaysian Institute of Personnel Management. Over the years, he has completed a considerable number of published researches on stress management, career development, creativity and mental health, youth problems in the national level. 